\title{
What Students Want? Exploring the Role of the Institution in Supporting Successful Learning Journeys in Online Distance Education
}

\author{
Dawn Mannay and Ceri Wilcock \\ Cardiff University; The Open University in Wales \\ Email: mannaydi@cardiff.ac.uk
}

\section{DOI: http://dx.doi.org/10.5456/WPLL.17.1.49}

\begin{abstract}
There have been numerous initiatives to increase access to higher education for those residing in marginalised locales in Wales. However, entrance in itself does not guarantee success and it is important for educators and policy makers to explore issues of retention. Classed and relational positionings often conflict with non-traditional students' education trajectories and sometimes contribute to their withdrawal from academia. In response to this challenge the current paper focuses on the accounts of non-traditional students in Communities First[1] areas who took an undergraduate social science module with The Open University in Wales. Importantly, rather than reading these barriers to progression as students' individual difficulties, the paper considers how educational cultures can create and perpetuate disadvantage. Exploring students' accounts of pedagogy and administration, the paper focuses on online provision in distance learning and offers a range of strategies that could potentially improve the delivery of an Open University module and students' experiences in future presentations.
\end{abstract}

Key Words: distance learning, higher education, online learning, new technologies, retention, and widening participation.

\section{Introduction}

Higher education is positioned as a gateway to opportunities. However, entrance to the academy and success within its institutions is highly differentiated. In Wales, UK, the Anatomy of Economic Inequality (Davies et al., 2011) provides quantitative evidence for the pervasive nature of classbased inequalities in education, demonstrating that an individual in social housing is approximately 10 times less likely to be a graduate compared to those in other types of accommodation. As Jenkins (2004, p.23) argues, for some organisations 'people production is at the core of their business' and therefore, universities are crucial sites of identity work where some will feel in place while others will be as 'a fish out of water'. 
Non-traditional students face complex psychological and structural barriers to accessing and completing higher education, which are well versed within the social sciences (Lucey et al, 2003; Mannay and Morgan, 2013; Mannay and O'Connell, 2013; Reay et al, 2010; Rose-Adams, 2013; Thomas, 2002; Ward, 2014). Academics and practitioners have charted the difficulties experienced by marginalised higher education students, employing theoretical models of hybridity (Lucey et al, 2003), habitus (Skeggs, 2010; Thomas, 2002), pedagogic identities (Reay, 2010) and psychological splitting (Mannay, 2013). This body of work has demonstrated the costs of divided learner identities along the lines of social class, however, such knowledge needs to be accompanied by action.

The National Equality Panel's report An Anatomy of Economic Inequality in the UK (Hills et al, 2010) demonstrated how inequalities in income and earnings in Britain are high, both temporally in relation to the position 30 years ago, and geographically compared with other industrialised nations. According to the Joseph Rowntree Foundation (2013), 23 per cent of the population in Wales live in low-income households, defined as below 60 per cent of median income, after housing costs. Furthermore, 31 per cent of children in Wales live in such households and working age poverty now stand at 58 per cent compared to 50 per cent in 2003 . However, education can be seen as a cause and effect of inequality, suggesting that policy interventions could potentially increase social mobility.

Consequently, in Wales, there has been an ideological commitment to ensure access to a wide demographic of participants from a range of social backgrounds. The Review of Higher Education in Wales (Welsh Government, 2009) presented a discourse of transformation, centralising social justice, partnerships, and widening access as its core aims; and the massification of higher education has brought some gains for non-traditional students. In particular, the Higher Education Funding Council for Wales (HEFCW) has invested considerable funding in projects of widening participation (Taylor et al., 2013), which are conceptualised as a vehicle 'to secure inclusion, progression and success in higher education to enable learners across all age ranges and backgrounds, who face the highest social and economic barriers, to fulfil their potential as students' (HEFCW, 2014, p.4).

For example, the HEFCW Reaching Wider regional partnerships model was an initiative set up in Wales to develop the educational progression and attainment of young people from disadvantaged backgrounds that focused on raising the aspirations of disadvantaged young people. The programme hoped that this would translate into participants perceiving an academic trajectory as possible, and consequently achieving a place in higher education (Hill and Hatt, 2012). Similarly, the Universities Heads of the Valleys Institute (UHOVI) emerged as a viable programme for change with an ambition to recruit students from areas of low economic productivity, 
educational exclusion, and social injustice. Specifically, the programme aimed to contribute to the regeneration of a former heavy industrial area in Wales, known as 'the valleys', improving job prospects and the quality of life for those living and working in the region (Saunders et al, 2013).

Evaluations of these programmes have demonstrated some success in widening participation to higher education for people from marginalised communities (Hill and Hatt, 2012; Moore and Dunworth, 2011; Saunders et al, 2013). Nevertheless, despite moves to bring non-traditional students into the academy, ideas of what it means to 'be a student' are largely governed by discourses of the traditional, young, middle-class student (Leathwood and O'Connell, 2003). Consequently, educational and institutional policy is often geared around an expectation that working-class, mature and nontraditional students need to 'fit-in' with middle-class ways of being (Abrahams and Ingram, 2013), an assumption that positions widening access as a fait accompli.

This is particularly problematic in a climate, conceptualised as the 'Learning Age', where lifelong learning and personal development is promoted as the gold standard for success in education and the labour market (Department for Employment and Learning, 2005). However, some of the structural barriers to accessing higher education for non-traditional students can be addressed by the flexibility offered by distance and online study. The Open University was founded in 1969 to offer degree programmes by distance learning across the UK in the form of 'correspondence materials, combined with television and radio broadcasts, video and audio recordings, tutorial support at a local level and (in some cases) week-long residential schools' (Richardson, 2009). However, in recent years, The Open University has made increasing use of computerbased support and conferencing links that are now commonly employed in distance learning modules (Price et al., 2007; Richardson, 2009; Thorpe, 2008).

Jones (2004, p. 89) defines this form of networked learning as 'learning in which information and communication technology is used to promote connections; between one learner and other learners, between learners and tutors; between a learning community and its learning resources'. However, some learners are unable to access these networks. Europe has 63 per cent of the global internet penetration (Internet World Stats, 2009), but significant disparities exist between levels of broadband access within Wales (National Assembly for Wales Commission, 2011). This raises questions around access to new technologies, as some students have reported difficulties with accessing online provision (Hara and Kling, 1999). There are arguments that the digital divide is becoming wider and deeper (Conole, 2011) and beyond issues of access there are other problems related to the introduction of new technologies. 
Richardson (2009, p.69) claims that 'institutions can feel confident about exploring the use of online forms of tutorial support'. This statement is convincing because of the key word 'exploring', rather than implementing. The academic literature demonstrates conflicting results in evaluating the implementation of online conferencing systems, in relation to face-to-face provision. For example, Richardson (2009) analysed the results of a Course Experience Questionnaire and a Revised Approaches to Studying Inventory that were completed by undergraduate Open University students on the level one course, titled 'Introduction to the Humanities' (module code A103), and the level three course, '20th Century Literature: Texts and Debates' (module code A300). Students on both courses were able to self-select between the options of being in a group that employed traditional face-to-face tutorials or one that used a version of online conferencing for tutorial support.

Richardson (2009) found no significant difference between students in the tuition conditions, face-to-face and online, in relation to both their perceptions of the academic quality of their course and the approaches to studying adopted on these courses. However, there are issues of sample base and methodology to consider when applying this finding more widely. The response rate of 48.7 percent means that more than half of the students did not reply and the findings only relate to those students who were willing to take part in the survey. There may be multiple reasons that questionnaires were not returned but there is also the possibility that students returning questionnaires may have a qualitatively different experience and perception of the course. This also brings up the issue of forced choice response, as students could only answer the questions asked. A complementary qualitative follow up with a sample of students may have provided a more nuanced insight into the differences between the two conditions.

The other important factor to keep in mind, when assessing the study, is that the students self-selected their form of tuition, either face-to-face or online. The element of choice is an important one as many distance courses do not offer an opportunity to choose the format of tutoring support. Students in the face-to-face cohort selected the reason 'because I prefer face-to-face tuition' at 67 per cent while in the online condition the reason 'because I prefer online tuition' was selected by 54 per cent of students. Accordingly, satisfaction rates can be linked to these initial preferences. Satisfaction could, therefore, be related to the concept of cognitive dissonance (Stone and Cooper, 2001). If a student were to give a negative appraisal it would be out of alignment with their initial stated preference, which would result in an uncomfortable cognitive dissonance. In contrast, a positive evaluation would avoid the negative feelings associated with dissonance and perhaps influence the responses to the questionnaires.

Consequently, Richardson's (2009) finding of no significant difference between students in the tuition conditions (face-to-face and online), may be compromised by the methodological issues discussed. In contrast, Price et 
al (2007) took a mixed methods approach that included a qualitative element, which allowed a more nuanced understanding of the student experience of engaging with online conferencing. Price et al (2007, p.14) made a clear distinction between tuition and tutoring, with tuition conceptualised as 'the teaching of a syllabus of knowledge' and tutoring 'conceived as a more subjective and personal activity that was designed to meet the needs of individual students'. Tutoring is related to changes in the person, not simply the retention of facts and information. This is a pastoral as well as an academic undertaking for tutors. As Price et al (2007, p.15) contend 'the academic and the personal will always be inextricably linked... tutors need not only to understand the course materials but also understand the students' - so in evaluating conferencing provision it is necessary to consider how well the tutor can understand the students in online compared to face-to-face settings.

Price et al (2007) also worked with a sample of undergraduate Open University students who were enrolled on a course titled International Development: Challenges for a World in Transition' (module code U213) and could select between face-to-face or online tutorial provision. Students completed the Course Experience Questionnaire and a Revised Approaches to Studying Inventory but also took part in qualitative interviews. In contrast to Richardson's findings there was a significant difference on the Course Experience Questionnaire, with students receiving face-to-face tuition giving higher scores than those enrolled for online tutorials. The significant differences were attributed to the subscales of participation in tutorials, relations with tutors, tutorial pace and good tutoring.

There were no significant differences in the Revised Approaches to Studying Inventory. However, in terms of academic attainment, students in the face-to-face cohort achieved an average grade of 62.06 , which was significantly different from the average of 55.12 in the online condition. In the associated qualitative interviews students argued that online provision 'does not have the same feeling of personal focus' and that 'there is no real substitute for face-to-face contact' (Price et al, 2007: 16). These criticisms of online conferencing can be linked to practical problems in accessing online systems, the lack of paralinguistic features and the competencies of individual tutors taking sessions.

The technical difficulties of accessing online conferencing have been documented in previous research studies (Hara and King, 1999). The timeframe of this research suggests that advancing technologies have not fully responded to the difficulties experiences by students. These problems can exist beyond the online conferencing programme because of inequalities in students' access to equipment (Albion et al., 2010; Kukulska-Hulme et al., 2011) and the pervasive nature of the digital divide (Conole, 2011; National Assembly for Wales Commission, 2011). Furthermore, as Richardson (2009, p.69) argues there are often difficulties with 
'transactional distance' in online provision because of the absence of paralinguistic information and these can be exacerbated if tutors do not receive adequate training (Albion et al., 2010; Price et al, 2007).

The World Wide Web 'has revolutionalised what is feasible for distance education' (Thorpe, 2008, p.59) and there is an argument that new technologies can contribute to flexible and dynamic delivery systems that meets students' expectations and needs (Welsh Government, 2013). However, in a context where online provision is becoming more centralised within distance education, it is important to continue to evaluate the impact of these changes on learners. Previous research has reported differential findings and this suggests that further studies are required to explore the opportunities and restrictions posed by online technologies.

'Retention is as important as recruitment' (Welsh Government, 2013, p.16), therefore, it is particularly important to engage with the student voice and include students who are more vulnerable to non-completion, such as those residing in marginalised areas. Success in higher education by individuals from Communities First cluster areas remains a long-term policy commitment in Wales (HEFCW, 2014). Consequently, the current paper aims to contribute to and extend the current knowledge in this area by exploring the subjective accounts of students residing in Communities First areas who enrolled on The Open University module titled 'Introduction to the Social Sciences' (module code DD131).

\section{The Study}

The Higher Education Academy funded project, 'Exploring the experience of part-time Communities First students at the start of their learning journey', took a broadly interpretivist approach. It was interested in the subjective views of students, but rather than being a purely academic exercise, there was an aim of identifying good practice and issues for improvement, aligning with action research. The approach engendered a move away from discourses of individual failure and a step towards an acknowledgement of the need for structural change within institutions. In particular, it was concerned with exploring the views of students from Communities First areas who had taken The Open University 30 credit undergraduate module titled 'Introduction to the Social Sciences' (module code DD131). The project was designed to offer an opportunity to reflect on and improve the delivery of the module, to make an existing situation more efficient and effective (Cohen et al, 2001).

'DD131 Introduction to the Social Sciences' offers a blended form of learning in that it supplies hard copy materials, written, visual and audio, and face-to-face tutorials alongside online activities, an asynchronous online support and discussion forum, and Elluminate tutorials. Elluminate is an online system that offers an audio conferencing facility used to support 
small group tutorials online where talk is in real time through the internet. Elluminate offers participants the opportunity to communicate synchronously using audio, written messages, on-screen whiteboard and share software applications. In order to explore students' experience of blended learning on 'DD131 Introduction to the Social Sciences', students were interviewed face-to-face and over the telephone.

The original sample for telephone interviews consisted of 17 students, two men and 15 women living in Community First areas, who had signed up for the module. Of these students, six had withdrawn from or deferred their course prior to the project. One of these withdrawn students was uncontactable as the phone number given was no longer in use and there was no response to the initial introductory email. Nine successful telephone interviews and four face-to-face interviews were conducted from this remaining sample of 16 students. Of these 13 students, one was a man and 12 were women. Three students had withdrawn/deferred from the module prior to the project. Therefore, the interviewed sample was representative of the whole sample.

It is suggested that researchers working on familiar territory can elicit greater understanding because cultural and linguistic barriers do not have to be negotiated and that participants may be more open (Atkinson et al., 2003; Henry, 2001). Additionally, shared knowledge and shared understanding can counter the severe imbalance with regard to intimacy and distance between interviewer and interviewee, which is often common in research interviews (Rogan and de Kock, 2005). As the researchers were a tutor on the module, Dawn Mannay, and an Educational Advisor, Ceri Wilcock, they shared a common knowledge of the course with the participants and there was also the potential for them to offer responses to participants' general queries and offer some immediate benefit in an advisory capacity, rather than simply act in the role of researcher.

However, there was also an imbalance in their positions, which was addressed to some extent as students who had been taught in Dawn Mannay's group were removed from the original sample. Both researchers still represented the institution of The Open University but relationships with students and tutors are arguably less hierarchical than those found in other student/teacher relationships. Therefore, perhaps a more salient issue for consideration is the point of familiarity, that in entering the research setting with preconceptions about the topic, researchers may be unable to notice that which is often taken for granted (Mannay 2010). In the interview process, then, it was important to acknowledge the disadvantages of preconceived understandings and try to counter the tacit and normalising effect of their own knowledge about the module. The interviews were relaxed in nature and participants seemed comfortable to discuss their experience as students on the module, which generated a large data set for analysis. 
As Kemmis (2006, p.459) contends, action research must be capable of 'telling unwelcome truths' and working collaboratively engenders an opportunity for multiple perspectives to be considered and for points of improvement to be actioned. Interviewing students about their subjective experience, face-to-face and on the telephone, facilitated an appraisal of strengths and areas for improvement in current practice. The interviews raised a number of themes namely: reasons for joining The Open University; reasons for choice of course; registration; hardcopy materials; online materials; tuition; assessment; work life balance; impression of The Open University; and withdrawal/deferral. However, in this paper we specifically focus on forms on interactive online provision as these have been presented as a way of eliminating barriers to participation (Andresen, 2009; Welsh Government, 2013).

\section{Evaluations of Online Learning}

Across the interview data was a consensus that The Open University's virtual learning environment 'Student home was really easy to navigate' and it would appear that this element of online provision, representing their home page and access point to further resources, has a well-designed, accessible and user friendly interface. In terms of the asynchronous online discussion forum, one student was unable to access this support system despite phoning the technical helpline, 'it was really difficult and I couldn't get on. I phoned the computer helpline and still couldn't get on'. Another student could not find any forum for her cohort, although she had actively engaged with the forum on other Open University courses.

This is problematic as there has been a move towards including forum activities on Open University modules that contribute to summative assessment, which is to some extent a response to the argument that there is a lack of student engagement with online interaction unless it is made compulsory (Kirkwood and Price, 2005). For example, The Open University course titled 'The Environmental Web' (module code U136) makes online interaction mandatory, as it contributes to marked assignments. This uncompromising approach is employed as it is seen as a way to enable practitioners to facilitate online interactions more easily, as they are already embedded into module design and assessments. Evaluation suggested that the course design facilitated a genuinely constructivist pedagogy and high levels of student satisfaction and engagement (Thorpe, 2008). This suggests that a strong course design characterised by mandatory online engagement allows practitioners a framework in which to develop successful learning communities, as long as students are able to access the forum to engage in these assessed tasks. 
In the current study, the forum was also positioned as an important source of knowledge and one student commented, 'I also now know that the level one course you only have to pass and it doesn't affect your degree grade - I only know this because someone asked about it on the forum'. Similarly, another student described the forum as a site of information sharing and said 'I used the forum at the beginning in October/November as people were posting up some questions about the first TMA' [2]. The absence of a forum was seen as a barrier to knowledge, as one student commented, 'Because there was no forum there were no links to recordings of Elluminate'. Therefore, it is important that tutors ensure that they are using the forum and providing adequate signposting for students to access this platform, in the welcome letter, tutorials and follow up emails.

Furthermore, although some students did not feel they needed to use the forum, for other students it formed part of an integral support system. For example, there were comments such as 'I made friends through the Open University buddy system by talking to people on the forum' and 'If you have a forum you can say 'what does that word mean?' and your tutor or other students will post up an answer and you are not so isolated'. The forum can also offer a route to course related activities and informal social networking. Previous research has demonstrated the ways in which friends and social networks can be an essential support system that helps to overcome social exclusion and increase student retention (Thomas, 2002). In the current study, students discussed how the forum acted as a link to social networking sites and expressed the significant part that Facebook played in their learning journeys and beyond their involvement with The Open University, as illustrated in the following quotes:

'Facebook groups really helped me to get through the assignments, I felt as though I was struggling and I was the only one; but the Facebook group reassured me that I wasn't the only one and other people were having the same problems. Facebook helped me to get through the course'

'The friends I made on the forum, I spoke to on Facebook and built a support system, this was great. Even when I stopped the course I still keep in contact with these new friends who have done really well with the Open University and got good grades. It is good to keep in contact and see they are doing well'

'On B120 [3] there is a forum and then you also start to talk on Facebook, it makes things easier'

'I joined the Facebook groups for DD131 and DSE141 [4]. The Facebook groups really helped me to get through the assignments, I felt as though I was struggling and I was the only one; but the Facebook group reassured me that I wasn't the only 
one and other people were having the same problems. Facebook helped me to get through the course'

Web 2.0 technologies, such as the free social networking website Facebook, can be exploited for learning and teaching and provide a support system. Facebook also offers students the opportunity to escape the 'guide on the side', the tutor who facilitates collaboration in online learning but, as Jones (2004) argues, also has significant power in relation to setting assessment tasks and grading assignments. Consequently, Web 2.0 technologies that operate outside institutional control may indeed reduce hierarchies and create spaces of ownership for students. Nevertheless, Facebook presents some difficulties for The Open University because it cannot be moderated in the same way as the forum.

As Conole (2011, p.402) contends, new technologies engender changes in the role of the tutor, including a 'loss of authority'. However, as demonstrated in the present study and in previous research (Jackson 2012), Facebook can also play an important supporting role in building friendships and networks. Therefore, arguably, students should be made aware of this provision, even if this information is given with the proviso that this is not an official or internally monitored social networking site.

Of all the online provision, Elluminate presented the greatest difficulties to students, which were sometimes overcome with technical support but in other cases students were unable to access this provision throughout the course, as illustrated in the following comments from the participants:

'I only had one problem and this was with Elluminate. I have a MAC [Apple Mac Computer] and it would not let me connect to Elluminate. I read the online guidance but I couldn't get on so in the end I just used my old Notebook instead and I managed to get online with this and join the Elluminate sessions'

'With the Forum and Elluminate it was really difficult and I couldn't get on. I phoned the computer helpline and still couldn't get on so I had to just go to face-to-face tutorials'

'All the time I was on the course I couldn't get on the forum or Elluminate, when I phone the helpline it was confusing, I didn't know what java script I had and if I had to download something. I just gave up in the end. I never got on the forum or Elluminate'

'With Elluminate it was really difficult and I couldn't get on. I emailed the computer helpline and they were helpful and sent a reply and I checked some stuff but I still couldn't get on. The email reply was helpful but it was a bit too technical so I couldn't understand what to do and I couldn't access any of the Elluminate classes. I could look at some of the Elluminate 
recordings after the classes had finished but I couldn't join in and it wasn't the same'

As Elluminate was developed to make tutorials accessible to all students and overcome barriers such as transport, child care and disability, this is problematic and more needs to be done in order to make the system accessible. The difficulties encountered by students suggest that it is important to have Elluminate tutorials early on in the module so that any problems with access can be resolved. It may also be useful to revise the advice provided by the helpline so that it provides clearer steps and illustrations for students to follow to overcome accessibility issues.

\section{Concluding Thoughts}

Overall, this research has drawn directly from the experiences of students and highlighted a number of difficulties that need to be addressed not at the level of the individual but by the delivering institution. In response a number of initiatives are in development with Student Support in The Open University in Wales. These will assist not only students residing in Communities First areas but all future students entering social sciences. These developments include the production of a 'Before you start' leaflet for students that tutors can send as part of their initial welcome message. This leaflet specifically offers advice to negate the particular problems reported with online forums and Elluminate. It also offers a balanced overview of Facebook social networking opportunities. Furthermore, the project has been instrumental in informing and delivering staff development sessions for tutors and the project findings have been disseminated to The Open University Students' Association and key internal stakeholders, such as The Open University in Wales' Teaching and Learning Group and The Open University in Wales' Directorate Team.

This paper was based on interviews with a small sample of students living in Communities First areas that enrolled on one Open University module and cannot be viewed as a representative of all students studying in online and distance education. However, as discussed in the previous sections, the interview data has raised some interesting points that could lead to a range of actions being considered for future provision. In this way, the study speaks to the HEFCW (2014) directive to promote and disseminate current and effective widening access practices across Wales, the UK and internationally.

This small scale study also suggests that it will be useful to carry out further consultations with students to explore and improve practice and contribute to making the existing situation more efficient and effective (Cohen et al, 2001). In particular, the paper contributes to the commitment to engaging with students who have been traditionally marginalised in systems of higher education in Wales, incorporating their views into the 
development of best practice in online education. Institutions need to be fully embedded in the communities they serve, and collaborative research that centralises the accounts of underrepresented students can ensure 'that Wales can continue to lead the way in having a truly accessible education system' (Welsh Government, 2013, p.17).

\section{References}

Abrahams, J. and Ingram, N. (2013) 'The Chameleon Habitus: Exploring Local Students' Negotiations of Multiple Fields', Sociological Research Online, 18, 4.

Albion, P.R., Loch, B., Mula, J.M. and Maroulis, J. (2010) 'Preparedness for Flexible Access to Learning Materials: How Ready are University Students and Staff?' in Steel, C.H., Keppell, M.J., Gerbic, P. and Housego, S. (eds) Curriculum, Technology and Transformation for an Unknown Future, Proceedings ascilite Sydney 2010 pp.25-35 http://www.ascilite.org.au/conferences/sydney10/Ascilite\%20conference $\% 20$ proceedings\%202010/Albion-full.pdf (accessed: 24 August 2014).

Atkinson, P., Coffey, A. and Delamont, S. (2003) Key Themes in Qualitative Research, Walnut Creek, CA, AltaMira Press.

Andresen, M. A. (2009) 'Asynchronous Discussion Forums: Success Factors, Outcomes, Assessments and Limitations', Educational Technology and Society, 12, 1: 249-257.

Cohen, L., Manion, L. and Morrison, K. (2000) Research Methods in Education, London: Routledge.

Conole, G. (2011) 'Stepping over the Edge: The Implications of New Technologies for Education' in Lee, M.J.W. and McLoughlin, C. (eds) Web 2.0-based Elearning: Applying Social Informatics for Tertiary Teaching, Hershey, PA, IGI Global.

Davies, R., Drinkwater, S., Joll, C., Jones, M., Lloyd-Williams, H., Makepeace, J., Parhi, M., Parken, A., Robinson, C., Taylor, C. and Wass, V. (2011) Anatomy of Economic Inequality in Wales, Wales Institute of Social and Economic Research Data and Methods, Research Report Series WISERD/RSS/002.

Department for Employment and Learning (2005) Lifelong Learning: A New Culture for All, Belfast, Department for Employment and Learning.

Hara, N. and Kling, R. (1999) 'Students' Frustrations with a Web-based Distance Education Course' [online], First Monday, 4, 12, http://firstmonday.org/htbin/cgiwrap/bin/ojs/index.php/ fm/ article/ view/ 710/ 620 (accessed: 21 July 2014).

Henry, A. (2001) 'Looking Two Ways: Identity, Research, and Praxis in the Caribbean Community', in B. Mercher and A. Ingram-Willis (eds) Multiple 
and Intersecting Identities in Qualitative Research, pp. 61-8. Mahwah, NJ: Lawrence Erlbaum.

Higher Education Funding Council for Wales (2014) Strategic Approach to Widening Access to Higher Education 2013/14 to 2015/16 Circular W14/32HE, Cardiff, Higher Education Funding Council for Wales.

Hill, M. and Hatt, S. (2012) Review of Widening Access and Reaching Wider Strategies in Wales, York, Higher Education Academy.

Hill, M. and Hatt, S. (2012) Review of Widening Access and Reaching Wider Strategies in Wales, York, Higher Education Academy.

Hills, J., Brewer, M., Jenkins, S., Lister, R., Lupton, R., Machin, S., Mills, C., Modood, T., Reese, T. and Riddell, S. (2010) An Anatomy of Economic Inequality in the UK: Report of the National Equality Panel, London, Government Equalities Office.

Internet World Stats (2009) 'Internet Usage in Europe: Internet User Statistics \& Population for 53 European Countries and Regions' [online], http://www.internetworldstats.com/stats4.htm (accessed: 6 June 2014).

Jackson, V. (2012) 'The Use of a Social Networking Site with Pre-enrolled Business School Students to Enhance their First Year Experience at University, and in Doing So, Improve Retention', Widening Participation and Lifelong Learning, 14 (Special Issue): 25-41.

Jenkins, R. (2004) Social Identities, $2^{\text {nd }}$ ed. London: Routledge.

Jones, C. (2004) 'Networks and Learning: Communities, Practices and the Metaphor of Networks', Association for Learning Technology Journal, 12, 1: 81-93.

Joseph Rowntree Foundation. (2013) Monitoring Poverty and Social exclusion in Wales 2013, York, Joseph Rowntree Foundation.

Kemmis, S. (2006) 'Participatory Action Research and the Public Sphere', Educational Action Research, 14, 4:459-76.

Kirkwood, A. and Price, L. (2005) 'Learners and Learning in the Twenty-first Century: What do we Know about Students' Attitudes Towards and Experiences of Information and Communication Technologies that will Help us Design Courses?', Studies in Higher Education, 30, 3: 257-274.

Kukulska-Hulme, A., Pettit, J., Bradley, L., Carvalho, A.A., Herrington, A., Kennedy, D. and Walker, A. (2011) 'Mature Students Using Mobile Devices in Life and Learning', International Journal of Mobile and Blended Learning, $3,1: 18-52$

Leathwood, C. and O'Connell, P. (2003) "'It's a Struggle": The Construction of the "New Student" in Higher Education', Journal of Educational Policy, 18, 6: 597-615.

Lucey, H., Melody, J. and Walkerdine, V. (2003) 'Uneasy Hybrids: Psychological Aspects of Becoming Educationally Successful for Working-class Young Women', Gender and Education, 15, 3: 285-299. 
Mannay, D. (2010) 'Making the Familiar Strange: Can Visual Research Methods Render the Familiar Setting More Perceptible?', Qualitative Research, 10,1: 91-111.

Mannay, D. (2013) 'Keeping Close and Spoiling Revisited: Exploring the Significance of 'Home' for Family Relationships and Educational Trajectories in a Marginalised Estate in Urban South Wales', Gender and Education, 25, 1: 91-107.

Mannay, D. and Morgan, M. (2013) 'Anatomies of Inequality: Considering the Emotional Cost of Aiming Higher for Marginalised, Mature Mothers Reentering Education', Journal of Adult and Continuing Education, 19, 1:57-75.

Mannay, D. and O'Connell, C. (2013) 'Accessing the Academy: Developing Strategies to Engage and Retain Marginalised Young People on Successful Educational Pathways', Socialiné Teorija, Empirija, Politika ir Praktika Social Theory, Empirics, Policy and Practice, 7: 133-140

National Assembly for Wales Commission (2011) Key Issues for the Fourth Assembly, Cardiff, National Assembly for Wales.

Price, L., Richardson, J.T.E. and Jelfs, A. (2007) 'Face-to-face Versus Online Tutoring Support in Distance Education', Studies in Higher Education, 32, 1: $1-20$.

Reay, D. (2010) 'Identity Making in Schools and Classrooms', In: M Wetherell and C.T. Mohanty, (eds). The Sage Handbook of Identities. London: Sage, pp. 277-294.

Reay, D., Crozier, G. and Clayton, J. (2010) 'Fitting in or Standing Out: WorkingClass Students in UK Higher Education', British Educational Research Journal, 32, 1: 1-19.

Richardson, J. T. E. (2009) 'Face-to-face Versus Online Tutoring Support in Humanities Courses in Distance Education', Arts and Humanities in Higher Education, 8, 69: 69-85.

Rogan A.I. and de Kock, D.M. (2005) 'Chronicles from the Classroom: Making Sense of the Methodology and Methods of Narrative Analysis', Qualitative Inquiry 11, 4: 628-49.

Rose-Adams, J. (2013) Leaving University Early: Exploring Relationships Between Institution Type and Student Withdrawal and Implications for Social Mobility', Widening Participation and Lifelong Learning, 15, 2: 96-112.

Saunders, D., Marshall, H., Cowe, F., Payne, R. and Rogers, A (2013) 'Developing Higher Education in South Wales: The Emergence of the Universities Heads of the Valleys Institute', Journal of Adult and Continuing Education, 19, 1: 76-100.

Skeggs, B. (2010) 'Class Culture and Morality: Legacies and Logics in the Space for Identification', In: M Wetherell and C.T. Mohanty, (eds). The Sage Handbook of Identities. London: Sage, pp. 339-360.

Stone, J. and Copper, J. (2001) 'A Self-standards Model of Cognitive Dissonance', Journal of Experimental Social Psychology, 37: 228-243. 
Taylor, C., Rees, G., Sloan, L. and Davies, R. (2013) 'Creating an Inclusive Higher Education System? Progression and Outcomes of Students from Low Participation Neighbourhoods at a Welsh university', Contemporary Wales 26: 138-161.

Thomas, L, (2002) 'Student Retention in Higher Education: The role of institutional habitus'. Australian Journal of Education Policy vol. 17, no.4 pp423-432

Thorpe, M. (2008) 'Effective Online Interaction: Mapping Course Design to Bridge from Research to Practice', Australasian Journal of Educational Technology, 24, 1: 57-72.

Ward, M. R. M. (2014) “I'm a Geek I am': Academic Achievement and the Performance of a Studious Working-class Masculinity', Gender and Education [online] http:/ / dx.doi.org/ 10.1080/ 09540253.2014.953918 (accessed: 11 September 2014).

Welsh Government (2009) For Our Future - The 21st Century Higher Education Strategy and Plan for Wales, Cardiff: Welsh Government.

Welsh Government (2013) Policy Statement on Higher Education, Cardiff: Welsh Government.

\section{End Notes}

1. Communities First areas correspond to the 100 most deprived electoral divisions according to the Welsh Index of Multiple Deprivation.

2. TMA is an abbreviation for Tutor-Marked Assignment. Open University student's continuous assessment is made up of tutormarked assignments (TMAs). TMAs in the module evaluated in the present study were in the form of essay questions.

3. B120 is the module code for the Open University undergraduate module titled 'An Introduction to Business Studies'.

4. DSE141 is the module code for the Open University undergraduate module titled 'Discovering Psychology'. 